\title{
Osmolytes: Proline metabolism in plants as sensors of abiotic stress
}

\author{
Ashu Singh*, Manoj Kumar Sharma and R. S. Sengar \\ Department of Agriculture Biotechnology, S. V. Patel University of Agriculture \& Technology, Meerut-250110 \\ (U. P.), INDIA \\ *Corresponding author. E-mail: ashubiot25@gmail.com
}

Received: February 19, 2016; Revised received: April 18, 2017; Accepted: September 28, 2017

\begin{abstract}
Proline accumulation occurs in a large range of plant species in retaliation to the numerous abiotic stresses. An exclusive research pattern suggests there is a pragmatic relation between proline accumulation and plant stress tolerance. In this review, we will discuss the metabolism of proline accumulation and its role in stress tolerance in plants. Pertaining to the literature cited clearly indicates that not only does it acts as an osmolyte, it also plays important roles during stress as a metal chelator and an antioxidative defence molecule. Moreover, when applied exogenously at low concentrations, proline enhanced stress tolerance in plants. However, some reports point out adverse effects of proline when applied at higher doses. Role of proline gene in seed germination, flowering and other developmental programmes; thus creation of transgene overexpressing this gene would provide better and robust plants. In this context this review gives a detailed account of different proline gene over-expressed in all the transgenic crops so far.
\end{abstract}

Keywords: Abiotic stress, Osmoprotectant, Proline, ROS, Transgenic

\section{INTRODUCTION}

Plants being exposed to different environmental stresses learn and or adopt to these stresses ina number of ways. Thus among these stresses, Osmolytes production stress, in particular that is caused due to abioteic stress such as drought and salinity is the most critical problem that limits plant growth and crop productivity in agriculture (Boyer, 1982). Plant physiological development and productivity is largely affected by many environmental stresses such as drought, high salinity, and low temperature. These stresses trigger expression of an array of gene in response. Thus the expressed products of these genes function not only in stress response but also in stress tolerance. In the signal transduction network from the first discrimination of stress signals to stress-responsive gene expression, many concerned transcription factors and cis-acting elements in the stress-induced promoters function for plant mitigation to environmental stresses. Recent a lot of advances have been made in studying the complex cascades of gene regulation in drought and cold stress responses, especially in identifying specificity and cross talk in stress signaling. In this review article, we highlight transcriptional regulation of gene expression in response to abiotic stresses, with particular emphasis on the role of transcription factors and cis-acting elements in stress-inducible promoters. Genes expressed during stress conditions function not only in protecting cells from stress by producing important metabolic products/bio-molecules, but also in regulating genes for signal transduction in the stress response. Thus, these gene products are classified into two groups (Fowler and Thomashow, 2002; Kreps et al., 2002; Seki et al., 2002). The primary group includes proteins that mainly function in stress subjection, such as osmotin, antifreeze proteins, chaperones, LEA (late embryogenesis abundant) proteins, RNA-binding proteins, and it also includes important catalyzing bio-molecules i.e enzymes for osmolyte biosynthesis such as water channel proteins, proline, sugar and proline transporters, The second group contains protein factors which play important role in regulation of signal transduction and gene expression machinery that probably works in response to stress reflex. This included an array of different transcription factors, suggesting that various transcriptional regulatory mechanisms function in the drought-, cold-, or high-salinity-stress signal transduction pathways (Seki et al., 2003). Many works indicate that there are more than 300 genes that have been identified as being stress -inducible (Kazuo and Kazuko, 2006). Among these different physiologically activated genes, more than half of the drought induced genes are also induced by high salinity, indicating the existence of significant cross talk between the drought and high-salinity responses. The section of small molecules known as "compatible osmolytes" includes certain amino acids (notably proline), quaternary ammonium compounds (e.g. glycinebetaine, proline betaine, $\beta$-alanine betaine, 
and choline- $O$-sulfate), and the tertiary sulfonium compound 3-dimethylsulfoniopropionate (DMSP). Throughout their life cycle, plants are subjected to various types of environmental stresses, water deficit, temperature extremes, toxic metal ion concentration and UV radiations depending upon the severity of stress. The environmental factors retard the growth and productivity of plants to different degrees. In reflex response to different stresses plants accumulate large quantities of different types of compatible solutes (Serraj and Sinclair, 2002). Thus accumulation of osmolyte compounds, usually called 'osmotic adjustment' or 'osmoregulation', is certainly a remedial measure to overcome the negative consequence of water deficite condition in plant's growth and survival. It has been proposed since long before as a remedial mechanism for drought and salt tolerance (Martin, 1930; Bernstein, 1961), but it has gained fame during the last 20 years. Compatible solutes are low molecular weight, highly soluble organic compounds that are usually non-toxic at high cellular concentrations. These solutes provide immunity, to plants from environmental-induced stress by regulating cellular osmotic adjustment, ROS detoxification, protection of membrane integrity and enzymes/protein stabilization (Ashraf and Foolad, 2005; Bohnert and Jensen, 1996; Yancey, 1994) These include proline, sucrose, polyols, trehalose and quaternary ammonium compounds (QACs) such as glycine betaine, alinine betaine, proline betaine and pipecolate betaine Exepidition of the action of these solutes would providea clear cut evidence to combat environmental stresses, which is important as it gives direct hope to genetically manipulate plants to withstand this condition. There are many cellular mechanisms by which organisms mitigate the effects of abiotic stresses; for instance, accumulation of compatible osmolytes such as proline is one such phenomenon. The phenomenon of proline accumulation is known to occur under water deficit (Naidu et al., 1991), Salinity (Munns, 2005; Rhodes and Hanson 1993), low temperature (Hare et al., 1998), heavy metal exposure (Bassi and Sharma, 1993a; Bassi and Sharma, 1993b; Schat et al., 1997; Sharma and Dietz, 2006) and UV radiations, etc. Apart from acting as osmolyte for osmotic adjustment, proline contributes to stabilizing sub-cellular structures (e.g., membranes and proteins), scavenging free radicals and buffering cellular redox potential under stress conditions (Ashraf et al., 2007). In many plant species, proline accumulation under salt stress has been correlated with stress tolerance, and its concentration has been shown to be generally higher in salt tolerant than in salt sensitive plants (Fougère et al., 1991; Gangopadhyay et al., 1997; Madan et al., 1995; Petrusa and Winicov, 1997). It may also act as protein compatible hydrotrope (Strizhov et al., 1997), alleviating cytoplasmic acidosis and maintaining appropriate $\mathrm{NADP}^{+} / \mathrm{NADPH}$ ratios compatible with metabolism. Work relating to this i.e proline osmoprotectant is reviewed here. Some generalizations can be made: Firstly, the availability of the precursor to synthesize the osmoprotectants could limit the amount of osmoprotectant made in a transgenic host. Secondly, negative physiological consequences of diverting the precursor to the osmoprotectants away from primary metabolism should be considered ( $\mathrm{Su}$ and $\mathrm{Wu}$ 2004). Thirdly, despite the availability of physiological data and techniques for assessing stress tolerance in plants, but still transgenic plants are rarely had been put to test their functioning which calls for their examination. Proline accumulation normally occurs in cytoplasm where it plays the role of molecular chaperons stabilizing/conditioning the structure of proteins and its accumulation by buffering cytosolic $\mathrm{pH}$ and maintaining cell redox status. It has also been proposed that its accumulation may be part of stress signal cascade influencing adaptive responses thus taking in account this feature would be beneficial to incur stress tolerance via engineering transgenic over expressing proline gene (Hoque et al., 2008).

\section{SENSORS OF ABIOTIC STRESS- OSMOLYTES}

There are many mechanisms at cellular level through which organisms ameliorate the effects of environmental stresses; for instance, accumulation of compatible osmolytes such as proline is one such phenomenon. Many plants, including halophytes, accumulate compatible osmolytes, such as proline (Pro), glycine betaine and sugar alcohols, when they are exposed to drought or salinity stress (Hellebust, 1976; Csonka, 1989; McCue KF, Hanson, 1990; Delauney and Verma, 1993). The accumulation of Pro has been observed not only in plants but also in eubacteria, marine invertebrates, protozoa, and algae (Delauney and Verma, 1993; Roosens et al., 2002). It has been suggested that compatible osmolytes do not interfere with normal biochemical reactions and act as osmoprotectants during osmotic stress. Among known compatible solutes, Proline is probably the most widely distributed osmolytes. Results of investigations of the relationship between the expression of these genes and the accumulation of Proline under water stress indicate that the level of Pro in plants is mainly regulated at transcriptional level during water stress. Moreover, the overproduction of Pro results in the increased tolerance of transgenic tobacco plants to osmotic stress. Thus tolerance to abiotic stress, especially to salt and improved plant growth, was observed in a variety of transgenics that were engineered for overproduction of proline (Kavi Kishor et al., 1995; Bohnert and Shen, 1999; Kavi Kishor et al., 2005). Proline seems to have diverse roles under osmotic stress conditions, such as stabilization of proteins, membranes and sub-cellular structures and protecting cellular functions by scavenging reactive 
oxygen species (Sasaki et al., 2005).

Salinity is detrimental to the various processes of crops such as seed germination, seedling growth and vigor, vegetative growth, flowering and fruit set and ultimately it causes diminished economic yield and also quality of produce (Stewart and Larher, 1980). Rice crop is important not only as food crop but also due to its medicinal value (Bajaj and Mohanty, 2005), due to virtue of it, it acts as a model monocot system for various biotechnological, metabolic, genetic engineering and functional genomics development studies worldwide (Munns and Tester, 2008). However, the yield of rice, especially Asian rice, is severely susceptible to salinity (Sairam et al., 2005). In India and especially the rainfed rice is hindered by three major abiotic stresses namely drought, submergence and Salinity (Rice Knowledge Management Portal, 2011).

\section{PROLINE AND ITS FUNCTION IN OSMOREG- ULATION}

Proline plays versatile functions in plants. As amino acid it is a one of the building blocks of protein structure, but it also plays a major role in of stress osmolytes solute under environmental stress conditions. Proline synthesis has been associated with tissues undergoing rapid cell divisions, such as shoot apical meristems, and appears to be involved in floral transition and embryo development. Lofty levels of proline can be found in pollen and seeds, where it serves as compatible solute, where it acts as dehydration protector of cellular structures during plant development. The agglomeration of proline at various terrain such as cells, tissues and other vital organs such as vascular bundles are controlled by reciprocity of biosynthesis, degradation, and cellular transport arcade. Thus, both the uniques properties of proline and its variegated action through two most widely studied transporter, both general amino acid permeases and selective compatible solute transporters indicates its prime position to be use in production of abiotic resilient plants engineered through manipulating it genes (Armengaud et al., 2004).

All the mechanisms encompassing the proline action be it accumulation or degradation shows that mechanisms regulating proline differ substantially from other amino acids (Yu et al., 1983). Proline accumulation is a common metabolic riposte, of higher plants to water deficits, and salinity stress, and has been the subject of numerous reviews over the last 20 years (Stewart and Larher, 1980; Thompson, 1980; Stewart, 1981; Hanson and Hitz, 1982; Samaras et al., 1995; Taylor, 1996; Rhodes et al., 1999). This versatile amino acid has highest water solubility and is accumulated by leaves of many halophytic higher plant species grown in saline environments (Stewart and Lee, 1974; Briens and Larher, 1982; Treichel, 1986), in leaf tissues and shoot apical meristems of plants undergoing water stress (Barnett and Naylor, 1966; Boggess et al., 1978; Jones et al., 1980) in desiccating pollen (Hongqi et al., 1982), in root apical regions growing at low water potentials (Voetberg and Sharp, 1991), and in suspension cultured plant cells reorganized to water stress (Tal and Katz, 1980; Rhodes, 1987), or $\mathrm{NaCl}$ stress (Tal and Katz, 1980; Rhodes and Handa, 1989; Thomas et al., 1992). Proline shields membranes and proteins against the adverse effects of elevated concentrations of inorganic ions and extreme temperature (Pollard et al., 1979; Paleg et al., 1981; Nash et al., 1982). Proline may also function as a protein-compatible hydrotrope (Srinivas and Balasubramaniam, 1995) and as a hydroxyl radical scavenger (Smirnoff and Cumbes, 1989). The proline gathered in response to water stress or salinity stress in plants is primarily confined in the cytosol (Leigh et al., 1981; Pahlich et al., 1981; Ketchum et al., 1991). In addition, the transient accumulation of proline, might serve as a safety valve to calibrate cellular redox state during stress (Shen et al., 1999; Kuznetsov and Shevyakova, 1999).

\section{PROLINE METABOLISM AND ITS IMPLICA- TIONS FOR PLANT-ENVIRONMENT INTER- ACTION}

Very high agglomeration of cellular proline (upto $80 \%$ of the amino acid pool under stress and 5\% under normal condition) has been documented in many plant species (Choudhary et al., 2005; Widodo et al., 2009). The increase in osmoprotectants is achieved either by amendment of metabolism (increasing biosynthesis and/or decreasing degradation) or by transport (increase uptake and/or decrease export) which also depends upon the type of stress and the type of species under consideration. Unlike other amino acids, proline has cyclized amino nitrogen that has significant influence on the conformation as well as uniqueness of polypeptides. Proline is also a prime component of structural proteins in animals and plants besides being a known osmoprotectants capable of mitigating the footprint of drought, salt, and temperature stress in plants (Rodriguez and Redman, 2005).

Proline, and its metabolism, is eminent from other amino acids in several ways. In plants proline is synthesized from glutamate as well from arginine/ ornithine. The most fundamental is that proline is the only one of the proteogenic amino acids where the a-amino group is present as a secondary amine. While this may seem like a distinction more important to chemists than plant biologists, the unique properties of proline are highly relevant to understanding its role in plants. Second important feature of proline has been studied a lot and recorded that its accumulation is caused by most of stresses relating to environmental stresses (Hare et al., 1998). The role of proline and 


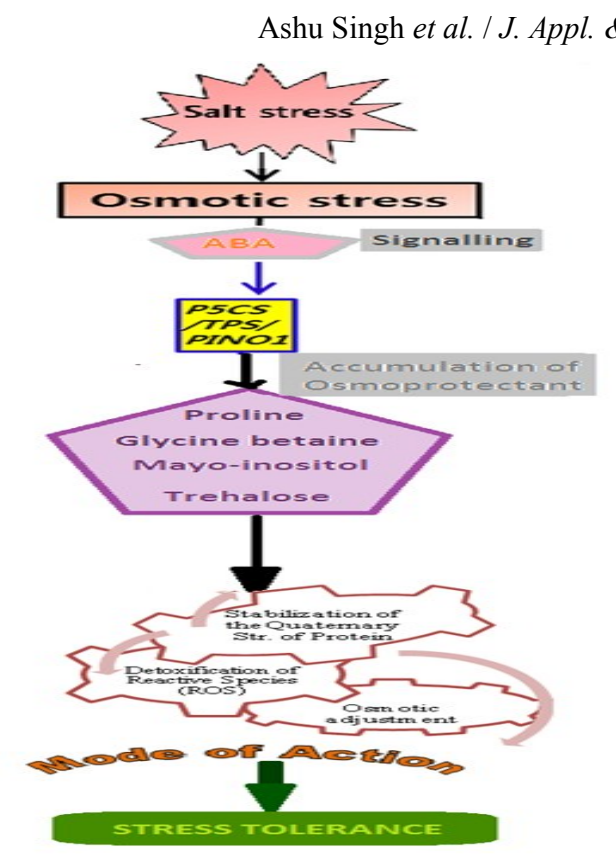

Fig. 1. An overview of salinity stress.

sulphur metabolism during osmotic stress tolerance in plants has been emphasized recently (Verma, 1999). Gene involved in biosynthesis of enzymes for biosynthesis and degradation of Proline is very well documented. Results of exploration of the relationship between the expression of these genes and the agglomeration of proline under deficit water stress indicate that the level of proline in plants is mainly regulated at micro-cellular transcriptional level during water stress. Moreover in this context, the overproduction of proline results in the increased tolerance of transgenic tobacco plants to osmotic stress was reported by Dobra et al. (2011).

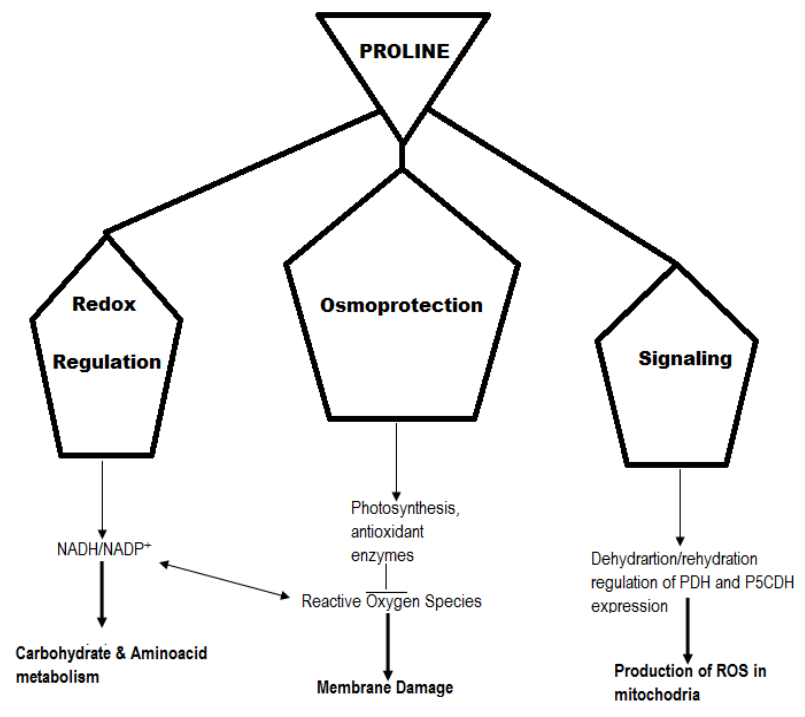

Fig. 2. Potential roles of proline during abiotic stress (Made by the author).
The basic of proline metabolism involves two enzymes catalyzing proline synthesis from glutamate in the cytoplasm or chloroplast, two enzymes catalyzing proline catabolism back to glutamate in the mitochondria, as well as an alternative pathway of proline synthesis via ornithine (Fig. 3). The inter conversion of proline and glutamate is sometimes referred to as the "proline cycle". The transcriptional up regulation of proline synthesis from glutamate and down regulation of proline catabolism during strain condition provides a conception to control proline levels, although inconsistency to this pattern has been observed (Stines et al., 1999). This is not the only side of the story however, as posttranslational modulation, of these enzymes has been little inspected and the role of ornithine as a proline precursor remains obscure (Phang, 1985). Likewise, the proline cycle may at first seem to be an ineffectual cycle; however, apprehending the intrinsic corporative modulation of this cycle and metabolic flux is the clue to understanding the proline metabolism biochemistry.

Proline not only being $\mathrm{n}$ important constituent of protein it is also a very versatile molecule playing a important part in osmoprotectant, cellular signal molecule during stress condition. After plant exposed to salt stress in Arabidopsis it accounted for $20 \%$ of the amino acid pool (Verbruggen et al., 1996). There are two different pathways in proline biosynthesis in higher plants: the ornithine and the glutamate pathways. The plant glutamate pathway is quite different from those in microbes and human. In bacteria and human, the conversion of glutamate to glutamate-5-semialdehyde (GSA) is catalyzed by two enzymes via two successive reactions, whereas, in higher angiosperms the conversion is catalyzed by a bi -functional enzyme in a single step reaction (Hu et al., 1992). This brings us to the conclusion that many research activities are being drawn specifically studying salinity and drought tolerance induced by proline (Williamson and Slocum, 1992).

The pathway for the biosynthesis of proline in plants was elucidated by reference to the pathway in Escherichia coli (Leisinger, 1987). Fig. 3 shows the proline biosynthesis and metabolism pathway in plants. The pathway in bacteria begins with the ATP-dependent phosphorylation of the $\gamma$-carboxy group of L-glutamic acid (L-G1U) by $\gamma$-glutamyl kinase $(\gamma-\mathrm{GK})$. The product of $\gamma-\mathrm{GK}$ is reduced to glutamic- $\gamma$ semialdehyde (GSA) by GSA dehydrogenase (GSADH), with which $\gamma$-glutamyl kinase forms an obligatory enzyme complex. GSA cyclizes spontaneously to form $\Delta^{1}$-pyrroline-5-carboxylate (P5C), which is finally reduced to proline by $\mathrm{P} 5 \mathrm{C}$ reductase (P5CR). It has been suggested that, in plants, proline is synthesized either from Glu or from ornithine and that the pathway from Glu is the primary route for the synthesis of Pro under conditions of osmotic stress and 
Table 1. Transgenic plants developed for abiotic stress tolerance through the manipulation of proline metabolism related genes.

\begin{tabular}{|c|c|c|c|c|}
\hline $\begin{array}{l}\text { S. } \\
\text { No. }\end{array}$ & Gene & Targeted Trait & Species & References \\
\hline \multirow[t]{39}{*}{1} & \multirow{39}{*}{$\begin{array}{l}\text { Pyrroline-5- } \\
\text { carboxylate } \\
\text { synthetase } \\
(P 5 C S)\end{array}$} & Salinity stress tolerance & \multirow{11}{*}{ Nicotiana spp. } & Kavi Kishor et al., 1995 \\
\hline & & Increased proline accumulation & & Zhang et al., 1995 \\
\hline & & Salinity stress tolerance & & Sokhansanj, et al., 2006 \\
\hline & & $\begin{array}{l}\text { Increased proline accumulation and osmotic } \\
\text { stress tolerance }\end{array}$ & & Yamchi et al., 2007 \\
\hline & & $\begin{array}{l}\text { Increased proline accumulation and salinity } \\
\text { stress tolerance }\end{array}$ & & $\begin{array}{l}\text { Razavizadeh and Ehsanpour, } \\
2009\end{array}$ \\
\hline & & Abiotic stress tolerance & & Dobra et al., 2010 \\
\hline & & $\begin{array}{l}\text { Increased proline accumulation and salinity } \\
\text { stress tolerance }\end{array}$ & & Jazii et al., 2011 \\
\hline & & Salinity stress tolerance & & Mahboobeh and Akbar, 2013 \\
\hline & & Salinity stress tolerance & & Ibragimova et al., 2015 \\
\hline & & Drought and salinity tolerance & & Zhu et al., 1998 \\
\hline & & $\begin{array}{l}\text { Increased proline accumulation and osmotic } \\
\text { stress tolerance }\end{array}$ & & Hong et al., 2000 \\
\hline & & Salinity stress tolerance & \multirow[t]{6}{*}{ Oryza sativa } & Anoop and Gupta, 2003 \\
\hline & & Drought and salt stress conditions & & $\mathrm{Su}$ and $\mathrm{Wu}, 2004$ \\
\hline & & $\begin{array}{l}\text { Enhanced salt and cold stress } \\
\text { tolerance }\end{array}$ & & Hur et al., 2004 \\
\hline & & Salinity stress tolerance & & Kumar et al., 2010 \\
\hline & & Salinity stress tolerance & & Karthikeyan et al., 2011 \\
\hline & & Drought and salinity stress tolerance & & Priva et al., 2015 \\
\hline & & Hypersensitivity to osmotic stress & \multirow[t]{3}{*}{ Arabidopsis thaliana } & Nanjo et al., 1999 \\
\hline & & Drought and salinity stress tolerance & & Chen et al., 2010 \\
\hline & & Salinity stress tolerance & & Chen et al., 2013 \\
\hline & & Salinity stress tolerance & Triticum aestivum & Sawahel and Hassan, 2002 \\
\hline & & $\begin{array}{l}\text { Proline accumulation and water stress toler- } \\
\text { ance }\end{array}$ & Triticum aestivum & Vendruscoloa et al., 2007 \\
\hline & & Tolerance to toxic heavy metals & $\begin{array}{l}\text { Chlamydomonas } \\
\text { reinhardii }\end{array}$ & Siripornadulsil et al., 2002 \\
\hline & & Salinity stress tolerance & Daucus carota & Han and Hwang, 2003 \\
\hline & & Drought stress tolerance & \multirow{2}{*}{ Citrus spp. } & Molinari et al., 2004 \\
\hline & & Drought stress tolerance & & De Campos et al., 2011 \\
\hline & & $\begin{array}{l}\text { Proline accumulation and salt } \\
\text { tolerance }\end{array}$ & Solanum tuberosum & Hmida-Sayari et al., 2005 \\
\hline & & $\begin{array}{l}\text { Cold, salt, and freezing stress } \\
\text { tolerance }\end{array}$ & Larix leptoeuropaea & Gleeson et al., 2005 \\
\hline & & Osmotic stress tolerance & Medicago truncatula & Verdoy et al., 2006 \\
\hline & & Water deficit stress tolerance & $\begin{array}{l}\text { Saccharum } \\
\text { officinarum }\end{array}$ & Molinari et al., 2007 \\
\hline & & $\begin{array}{l}\text { Proline accumulation and salt } \\
\text { tolerance }\end{array}$ & Cicer arietinum & Ghanti et al., 2011 \\
\hline & & Salinity stress tolerance & Olea europaea & Behelgardy et al., 2012 \\
\hline & & Salinity stress tolerance & Lilium spp. & Li et al., 2013 \\
\hline & & Drought stress tolerance & $\begin{array}{l}\text { Hordeum vulgare } \\
\text { var. nudum }\end{array}$ & Deng et al., 2013 \\
\hline & & Proline accumulation and salt tolerance & Cajanus cajan & Surekha et al., 2014 \\
\hline & & Proline accumulation and salt tolerance & $\begin{array}{l}\text { Saccharum officinar- } \\
\text { um }\end{array}$ & Guerzoni et al., 2014 \\
\hline & & $\begin{array}{l}\text { Proline accumulation and salt } \\
\text { tolerance }\end{array}$ & Sorghum bicolor & Surender Reddy et al., 2015 \\
\hline & & Salinity stress tolerance & Brassica napus & Szymon et al., 2015 \\
\hline & & Salinity stress tolerance & Nicotiana tabacum & LaRosa et al., 1991 \\
\hline \multirow[t]{3}{*}{2} & \multirow{3}{*}{$\begin{array}{l}\text { Pyrroline-5- } \\
\text { carboxylate } \\
\text { reductase } \\
(P 5 C R)\end{array}$} & Enhanced heat and drought stress tolerance & Glycine $\max$ & De Ronde et al., 2000 \\
\hline & & $\begin{array}{l}\text { Osmotic and drought stress tolerance } \\
\text { Salinity, drought and ABA stress tolerance }\end{array}$ & Arabidopsis thaliana & $\begin{array}{l}\text { De Ronde et al., } 2004 \\
\text { Ma et al. } 2008\end{array}$ \\
\hline & & Salinity stress tolerance & Ipomea batata & Liu et al., 2014 \\
\hline
\end{tabular}


Table 1. Contd.

\begin{tabular}{|c|c|c|c|c|}
\hline \multirow{8}{*}{3} & \multirow{8}{*}{$\begin{array}{l}\text { Proline } \\
\text { dehydrogenase } \\
(\text { ProDH })\end{array}$} & Salt and freezing stress tolerance & Arabidopsis thaliana & Nanjo et al., 1999 \\
\hline & & Hypersensitivity to proline & & Mani et al., 2002 \\
\hline & & Elevated salt tolerance & Nicotiana tabacum & Kolodyazhnaya et al., 2006 \\
\hline & & $\begin{array}{l}\text { Increased proline content and drought } \\
\text { stress tolerance }\end{array}$ & Nicotiana tabacum & Kochetov et al., 2004 \\
\hline & & Enhanced water stress tolerance & Arabidopsis thaliana & Ueda et al., 2008 \\
\hline & & $\begin{array}{l}\text { Over-expression for Osmotic stress } \\
\text { tolerance }\end{array}$ & $\begin{array}{l}\text { Arabidopsis thaliana } \\
\text { and Nicotiana tabacum }\end{array}$ & Miller et al., 2009 \\
\hline & & $\begin{array}{l}\text { Salinity and water stress tolerance through } \\
\text { elevated proline content }\end{array}$ & Nicotiana tabacum & Ibragimova et al., 2012 \\
\hline & & Enhanced oxidative stress tolerance & Arabidopsis thaliana & Monteoliva et al., 2014 \\
\hline 4 & ProBA & $\begin{array}{l}\text { Increased proline content and drought } \\
\text { stress tolerance }\end{array}$ & Arabidopsis thaliana & Chen et al., 2007 \\
\hline \multirow[t]{3}{*}{5} & \multirow{3}{*}{$\begin{array}{l}\text { Ornithine- } \delta \text { - } \\
\text { aminotransfer- } \\
\text { ase }(\delta \text {-OAT) }\end{array}$} & $\begin{array}{l}\text { Increased proline biosynthesis and osmo- } \\
\text { tolerance }\end{array}$ & Nicotiana tabacum & Roosens et al., 2002 \\
\hline & & Drought and salinity tolerance & Oryza sativa & Wu et al., 2003 \\
\hline & & Multiple abiotic stress tolerance & & You et al., 2012 \\
\hline
\end{tabular}

nitrogen limitation, while the pathway from ornithine predominates at high levels of available nitrogen (Delauney et al., 1993).

The other degree that controls production of Pro in plants is the degradation or metabolism of Pro. L-Proline is oxidized to $\mathrm{P} 5 \mathrm{C}$ in plant mitochondria by proline dehydrogenase (oxidase) (ProDH; EC 1.5.99.8), and P5C is converted to L-G1U by P5C dehydrogenase (P5CDH) (Boggess et al., 1975; Elthon and Stewart, 1981). Such oxidation of Pro is repressed during the buildup of Pro under water stress and is triggered in rehydrated plants (Stewart et al., 1977; Rayapati and Stewart, 1991). ProDH and P5CDH catalyze reactions that are the opposite of those catalyzed by P5CS and P5CR, respectively, in the biosynthesis of Proline. Although stress-induced proline accumulation is evolutionarily conserved in a wide range of plants, its regulatory mechanism is subject to considerable variation. In most plant species studied, proline accumulation during stress is the result of reciprocal action of increased biosynthesis and inhibited degradation (Kavi Kishor et al., 2005).

\section{DEGRADATION OF PROLINE}

Proline degradation in eukaryotes takes place in mitochondria and thus in plants are compartmentalized spatially from the biosynthetic pathway. The catabolism of Proline commences with the oxidation of proline to $\mathrm{P} 5 \mathrm{C}$ by proline dehydrogenase (PDH), using FAD as cofactor. $\mathrm{P} 5 \mathrm{C}$ is sequentially converted to glutamate by pyrroline-5-carboxylate dehydrogenase (P5CDH) using $\mathrm{NAD}^{+}$(Fig. 3). Whereas in eukaryotes two enzymes catalyze these sequential steps in proline degradation, in bacteria both mono- and bifunctional enzymes exist (Tanner, 2008). Two homologous genes have been diagnosed to encode proline dehydrogenase in Arabidopsis and tobacco (Mani et al., 2002; Ribarits et al., 2007; Verbruggen and Hermans, 2008; Funck et al., 2008), while the available literature is scarce. In contrast, the enzyme catalyzing the second step of proline degradation $(\mathrm{P} 5 \mathrm{CDH})$ is ciphered by a single copy gene in all monocot and dicot species analyzed so far (Ayliffe et al., 2005; Deuschle et al., 2006; Mitchell et al., 2006). Biochemical investigation revealed the presence of two P5CDH activities with slightly divergent characteristics in Nicotiana plumbaginifolia and Zea mays (Elthon and Stewart, 1982; Forlani et al., 1997). But the present scenario does not clearly reveal that whether both activities arise from a single gene or if a second $\mathrm{P} 5 \mathrm{CDH}$ gene is exist in these species.

Role of proline metabolism in plant for interaction and development of stress tolerance: $I t$ is or it is not the agglomeration proline responsible for adaptive retaliation; to abiotic stress has been argued since Kemble and McPherson (Kemble and Macpherson, 1954) first documented proline accumulation in wilted ryegrass. Evident correlations between high proline and greater stress caused injury led to conclude that proline was the first manifestation of damage which results in decreased growth and metabolism rather than an adaptive retaliation (Stewart and Hanson, 1980). Indeed, it seems contradictory that plants synthesize large amounts of proline and at the same time restricting carbohydrate biosynthesis by restricting photosynthesis which severely retards growth and reproductive performance during drought (Boyer, 2010). However, controlled experiments demonstrated that proline agglomeration occurs even in plant tissues/cell where growth prevails and injury is nominal (Voetberg and Sharp, 1991; Ober and Sharp, 1994) and also occurs to remarkable extent under mild and moderate stress treatments (Sharma and Verslues, 2010). Proline also accumulates to elevated high levels in pollen and this is likely related to pollen desiccation tolerance (Schwacke et al., 1999). Moreover, a number of groups have pointed out a higher proline in more drought adapted varieties of wild or cultivated plants (Ben Hassine et al., 2008; Parida et al., 2008; Evers et 


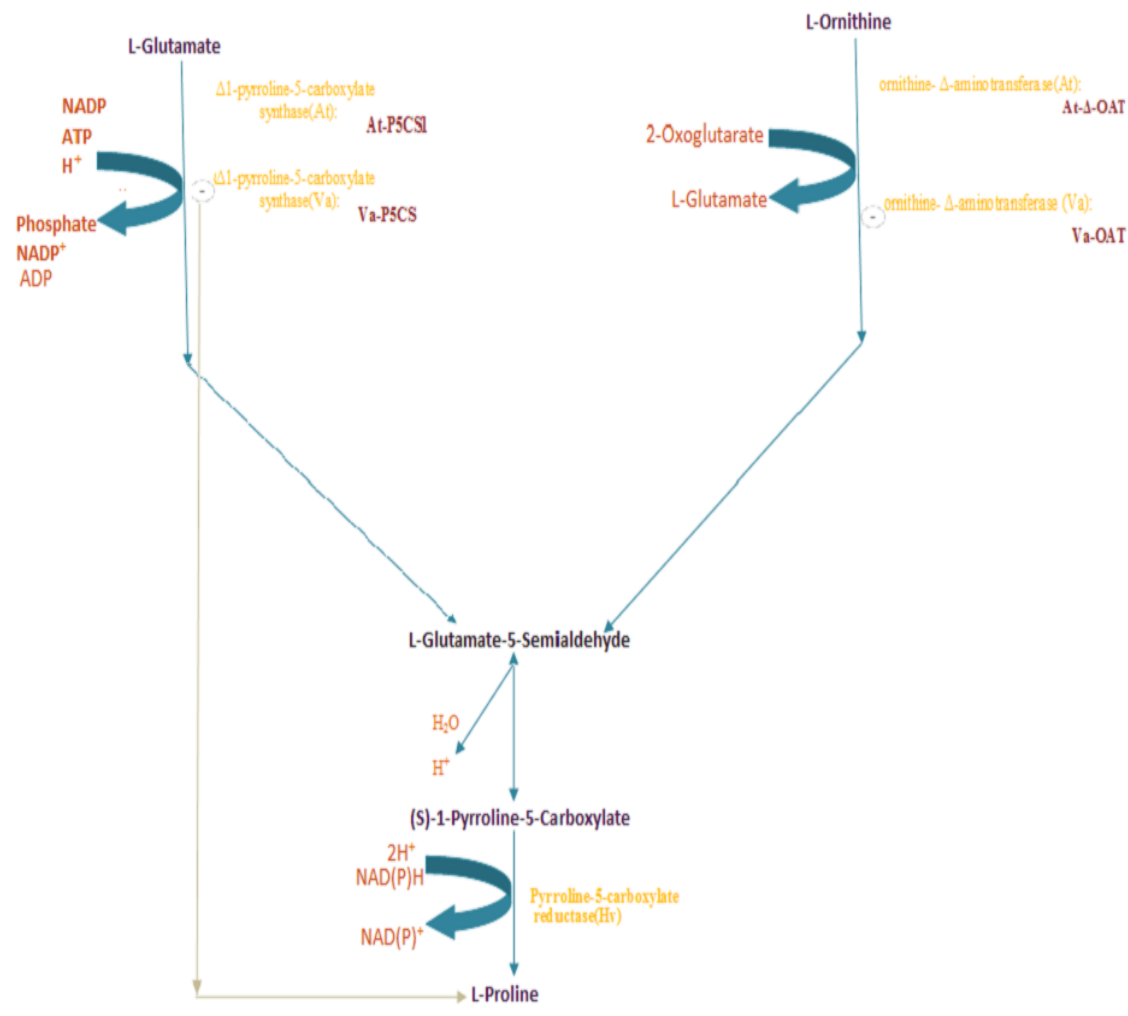

Fig. 3. Pathways for the biosynthesis and metabolism of proline in higher plants (http://themedicalbiochemistry page.org/amino -acid-metabolism.php).

al., 2010). Also, the salt-tolerant Arabidopsis relative Thellungiella halophila agglomerates more proline at salinity stress than the standard Columbia-0 ecotype of Arabidopsis (Kant et al., 2006). Proline play a role as a precursor for proline- or hydroxyproline-betaines which is even more effective osmoprotectants for plants in acute dry environments (Hanson et al., 1994). With advancement of molecular techniques data has clearly indicated that proline metabolism is actively controlled by stress induced signals and the usage of reverse genetics (such as p5cs1 mutants; Szekely et al., 2008) has made possible a more direct tests of the requirement of proline accumulation for stress resistance. The main challenging question is how proline contributes to plant stress resistance, the metabolic modulation that allows elevated levels of proline to accumulate, and whether fine-tuning of proline metabolism is useful for biotechnological improvement of plants which is yet to be answered.

Genetic engineering for abiotic stress tolerance By overexpression of proline genes: Metabolic engineering is the directed improvement of cellular properties through the modification of species biochemical reactions or the introduction of new ones, with the use of recombinant DNA technology (Stephanopoulos, 1999). Osmoprotectant accumulation is only one facet of a myriad of stress-tolerant traits found in nature.
Since oxidative stress is a component of drought and salinity, manipulations aimed at improving oxidative stress tolerance have also resulted in salinity tolerance (Roxas et al., 1997). This could be done either via repeatedly engineering the gene or by crossing and selecting transgenic plants engineered for different traits. For example, manipulation of genes involved in ion transport together with osmoprotectant synthesis can be expected to increase a cell's ability to withstand salinity stress. The gene products involved in ion homeostasis have been identified by the use of yeast model systems (Serrano et al., 1999) and by analyzing mutants altered for salt sensitivity $(\mathrm{Wu}$ et al., 1996; Liu et al., 2000). Osmoprotectant synthesis in naturally stress-tolerant species is highly regulated by stress. In addition to the use of stress inducible promoters for engineering osmoprotectant synthesis pathways, genes involved in stress signal sensing are additionally useful for engineering stress tolerant plants.

Stress tolerance via proline: Kavi Kishor et al. (2005) reported over expression of proline in transgenic tobacco and the transgenic plants produced increased root biomass under moisture deficient stress. While in one other recent study, the OsP5CS1 and OsP5CS2 genes were co-expressed in tobacco that conversed transgenic plants with high 
levels of proline accumulation as well as reduced oxidative harm to cells under abiotic stress conditions (Zhang et al., 2005). Similar proline production was also reported in transgenic rice, wheat and carrot plants overexpressing P5CS gene that showed resistance to salinity stress (Zhu et al., 1998; Sawahel et al., 2002; Han et al., 2003).

Transgenic Arabidopsis plants that expressed P5CS antisense gene were constitute with morphological aberrations, and the plants were hypersensitive to water-influx stress which was seen by Nanjo et al. (1999). In addition to playing a role in safeguarding vital proteins, it was also projected that proline would play a viable, role in ROS scavenging; this was conceptualized by Smirnoff and Cumbes (1989). In transgenic Arabidopsis P5CS mutant lines, it was proposed that the ROS scavenging enzymes demonstrated significantly lower activities. This evidence clearly points out the possibilities that either proline protects the enzymes of the glutathioneascorbate cycle or increases their activities during osmotic stress. Hmida-Sayari et al. (2005) concluded a study of transfer the Arabidopsis P5CS gene into potato in which the stress induced promoter got activated as a result of stress condition and thus its subsequent effect was observed on the plant's growth, tuber morphology and yield and the data compiled accordingly. Transgenic potato plants accumulated high proline content compared to those at control under high salt stress $(100 \mathrm{mM} \mathrm{NaCl})$ and, in turn, exhibited improved salinity tolerance by diminished tuber yield and weight when compared to that of non-transgenic control. In addition, some other studies were conducted on transgenic petunias and pigeon pea (Cajanus cajan) with the P5CS gene that rendered these plants abiotic stress tolerant (Surekha et al., 2013). Petunia was modified with pyrroline -5- carboxylate Synthetase genes (AtP5CS from A. thaliana L. or OsP5CS from Oryza sativa L.) the results showed more proline production which resulted in water stress tolerance for a period of 14 days. Modified pigeon pea was also mutagenized with the alternate version (P5CSF 129A) of wild P5CS gene from Vigna aconitifolia. The resultant transgenic plants showed enhanced level of proline content than their non-transgenic counterparts. About four times higher proline content was observed in the $\mathrm{T}_{1}$ transgenic plants compared to that of nontransgenic under $200 \mathrm{mM} \mathrm{NaCl}$ stress, this study was done by Surekha et al. (2013). As a result of correspondingly levels high proline accumulation, under salt stress the transgenic plants displayed more chlorophyll, better growth, and relative water content and reduced levels of lipid peroxidation. These findings indicated the importance of proline biosynthesis in transgenic plants when compared osmotic stress induced by salt and drought stresses.
Huang et al. (2013) have scrutinized HtP5CS, HtOAT and HtPDH enzyme activities and gene expression mosaic of putative HtP5CS1, HtP5CS2, HtOAT, $H t P D H 1$, and $H t P D H 2$ genes. Ashfaque et al. (2014) applied $\mathrm{H}_{2} \mathrm{O}_{2}$ on plants to demonstrated the different parameters related to water and salinity stress. The application of both 50 and $100 \mathrm{nM} \mathrm{H}_{2} \mathrm{O}_{2}$ minimized the extremity of salt stress by reducing the level of $\mathrm{Na}^{+}$ and $\mathrm{Cl}^{-}$content; and thereby elevating the levels of proline and $\mathrm{N}$ assimilation. The outcome was increased water relations, photosynthetic pigments and growth under salinity stress. This was evident even under non saline condition where application of $\mathrm{H}_{2} \mathrm{O}_{2}$ increased all the parameters under study. Szymon et al. (2015) showed the role of priming-induced modulation of activities of concerned genes and proline turnover enzymes, and its interplay with higher levels of hydrogen peroxide, in enhancing the seed germination capability under various stress. During the events such as priming and post-priming germination the buildup of proline was analogous with strong up-regulation of the P5CSA gene, down-regulation of the $P D H$ gene along with production of hydrogen peroxide. P5CSA transcript was up-regulated which was found in consistent with the expanded activity of P5CS gene and the other genes intricate such as ornithine- $\delta$ aminotransferase (OAT), pyrroline-5-carboxylate synthetase (P5CS), and proline dehydrogenase (PDH) was examined in detail which clearly indicated the role of proline biosynthesis as well as proline metabolism genes in rendering plant tolerant to various abiotic stresses.

\section{Conclusion}

Fabricating transgenic plants utilizing biotechnological approaches has become an eminent tool in plant-stress biology. The abiotic stresses effects the plant at all possible levels of organization i.e. morphological, physiological, biochemical and molecular which demands attention. Thus comprehending the apparatuses that regulate gene expression and the possibility to transfer genes from other organisms into plants will definitely expand our horizon to master the plant genetically. The use of new and useful approaches combining molecular genetics, physiological, biochemical and other related techniques will definitely provide us the better understanding to exploit it to the prime extent to get mastered transgenic crops. The abiotic stresses such as salinity and drought are more complex traits, controlled by many genes. Transgenic plant development for these stresses has utilized many single genes. However, much emphasis has been placed on Proline, its function and metabolism. This review focuses on the current status of research on osmoprotectant proline genetic engineering and their overexpression to abiotic stress tolerance in transgenic plants.

\section{ACKNOWLEDGMENTS}

The authors express their acknowledgements to the Woman Scientist scheme-A, Department of Science and Technology, Ministry of Science and Technology, and SVP University of 
Agriculture and Technology Meerut India for the financial and technical support to conduct activities on research program

\section{REFERENCES}

Anoop, N. and Gupta, A.K. (2003). Transgenic indica rice cv IR-50 over-expressing Vigna aconitifolia $\Delta^{1}$-pyrroline-5 -carboxylate synthetase cDNA shows tolerance to high salt. Journal of Plant Biochemistry and Biotechnology, 12: 109-116.

Armengaud, P., Thiery, L.R., Buhot, N.O., Grenier, D., March, G. and Savoure, A.D. (2004). Transcriptional regulation of proline biosynthesis in Medicago truncatula reveals developmental and environmental specific features. Physiologia Plantarum, 120: 442-450.

Ashraf, M. and Foolad, M.R. (2005). Roles of glycine betaine and proline in improving plant abiotic stress resistance. Environmental and Experimental Botany, 59: 206-16.

Ayliffe, M.A., Mitchell, H.J., Deuschle, K. and Pryor, A. J. (2005). Comparative analysis in cereals of a key proline catabolism gene. Molecular Genetics and Genomics, 274: 494-505.

Bajaj, S. and Mohanty, A. (2005). Recent advances in rice biotechnology towards genetically superior transgenic rice. Plant Biotechnology Journal, 3: 275-307.

Barnett, N.M. and Naylor, A.W. (1966). Amino acid and protein metabolism in Bermuda grass during water stress. Plant Physiology, 41: 1222-1230.

Bassi, R. and Sharma, S.S. (1993a). Changes in proline content accompanying the uptake of zinc and copper by Lemna minor. Annals of Botany, 72: 151-154.

Bassi, R. and Sharma, S.S. (1993b). Proline accumulation in wheat seedlings exposed to zinc and copper. Phytochemistry, 33: 1339-1342.

Behelgardy, M.F., Motamed, N. and Jazii F.R. (2012). Expression of the P5CS gene in transgenic versus non-transgenic olive (Olea europaea) under salinity stress. World Applied Sciences Journal, 18: 580-583.

Ben Hassine, A., Ghanem, M.E., Bouzid, S., and Lutts, S. (2008). An inland and a coastal population of the Mediterranean xero-halophyte species Atriplex halimus L. differ in their ability to accumulate proline and glycinebetaine in response to salinity and water stress. Journal of Experimental Botany, 59: 1315-1326.

Bernstein, L. (1961). Osmotic adjustment of plants to saline media. I. Steady state. American Journal of Botany, 48: 909-918.

Boggess, S.F., Aspinall, D. and Paleg, L.G. (1976). Stress metabolism. IX. The significance of end-product inhibition of proline biosynthesis and of compartmentation in relation to stress-induced proline accumulation. Australian Journal of Plant Physiology, 3: 513-525.

Boggess, S.F., Paleg, L.G. and Aspinall, D. (1975). $\Delta^{1}-$ pyrroline-5-carboxylic acid dehydrogenase in barley, a proline-accumulating species. Plant Physiology, 56: 259 -262 .

Bohnert HJ, Jensen RG. (1996). Strategies for engineering water-stress tolerance in plants. Trends in Biotechnology, 14: 89-97.

Bohnert, H.J. and Shen, B. (1999). Transformation and compatible solutes. Scientia Horticulturae, 78: 237-260.

Boyer, J.S. (1982). Plant productivity and environment.
Science, 218: 443-448

Boyer, J.S. (2010). Drought decision-making. Journal of Experimental Botany, 61: 3493-3497.

Briens, M. and Larher, F. (1982). Osmoregulation in halophytic higher plants: a comparative study of soluble carbohydrates, polyols, betaines and free proline. Plant Cell and Environment, 5: 287-292.

Chen, M., Wei H., Cao J., Liu, R., Wang, Y. and Zheng C. (2007). Expression of Bacillus subtilis proBA genes and reduction of feedback inhibition of proline synthesis increases proline production and confers osmotolerance in transgenic Arabidopsis. Journal of Biochemistry and Molecular Biology, 40: 396-403.

Chen, J.B., Zhao, L.Y. and Mao, X.G. (2010). Response of PvP5CS1 transgenic Arabidopsis plants to drought and salt-stress. Acta Agronomica Sinica, 36: 147-153.

Chen, J.B., Yang, J.W., Zhang Z.Y., Feng X.F., Wang, S.M. (2013). Two P5CS genes from common bean exhibiting different tolerance to salt stress in transgenic Arabidopsis. Journal of Genetics, 92: 461-469.

Choudhary, N.L., Sairam, R.K. and Tyagi, A. (2005). Expression of delta1-pyrroline-5- carboxylate synthetase gene during drought in rice (Oryza sativa L.). Indian Journal of Biochemistry and Biophysics, 42: 366-370.

Csonka, L. (1989). Physiological and genetic responses of bacteria to osmotic stress. Microbiology Reviews, 53: 121-147.

De Campos, M.K.F., De Carvalho, K., De Souzaa, F.S., Marura, C.J., Pereira, L.F.P., Filhoc, J.C.B. and Vieira, L.G.E. (2011). Drought tolerance and antioxidant enzymatic activity in transgenic 'Swingle' citrumelo plants over-accumulating proline. Environmental and Experimental Botany, 72: 242-250.

De Ronde, J.A., Spreeth, M.H. and Cress, W.A. (2000). Effect of antisense- $\Delta^{1}$-pyrroline-5-carboxylate reductase transgenic soybean plants subjected to osmotic and drought stress. Plant Growth Regulation, 32: 13-26.

De Ronde, J.A., Cress, W.A., Kruger, G.H.J., Strasser, R.J. and Van Staden, J. (2004). Photosynthetic response of transgenic soybean plants, containing an Arabidopsis P5VR gene, during heat and drought stress. Journal of Plant Physiology, 161: 1211-1224.

Delauney, A.J. and Verma, D.P.S. (1993). Proline biosynthesis and osmo-regulation in plants. Plant Journal, 4: 215223.

Deng, G., Liang, J., Xu, D., Long, H., Pan, Z. and Yu, M. (2013). The relationship between proline content, the expression level of P5CS ( $\Delta^{1}$-Pyrroline-5-Carboxylate Synthetase), and drought tolerance in Tibetan hulless barley (Hordeum vulgare var. nudum). Russian Journal of Plant Physiology, 60(5): 693-700.

Deuschle, K., Funck, D., Hellmann, H., Diischner, K., Binder, S. and Frommer, W.B. (2001). A nuclear gene encoding mitochondrial $\Delta^{1}$-pyrroline-5-carboxylic acid dehydrogenase and its potential role in protection from proline toxicity. Plant Journal, 27: 345-355.

Dobra, J., Motyka, V., Dobrev, P., Malbeck, J., Prasil, I.T., Haisel, D., Gaudinova, A., Havlova, M., Gubis, J. and Vankova, R. (2010). Comparison of hormonal responses to heat, drought and combined stress in tobacco plants with elevated proline content. Journal of Plant Physiology, 167: 1360-1370. 
Dobra, J., Vankov, R.S., Havlov, M., Burman, A.J., Libus, J. and Storchov, H. (2011). Tobacco leaves and roots differ in the expression of proline metabolism-related genes in the course of drought stress and subsequent recovery. Journal of Plant Physiology, 168: 1588-1597.

Elthon, T.E. and Stewart, C.R. (1981). Sub mitochondrial location and electron transport characteristics of enzymes involved in proline oxidation. Plant Physiology, 67: $780-784$

Elthon, T.E. and Stewart, C.R. (1982). Proline oxidation in corn mitochondria: involvement of NAD, relationship to ornithine metabolism, and sidedness on the inner membrane. Plant Physiology, 70: 567-572.

Evers, D., Lefevre, I., Legay, S., Lamoureux, D., Hausman, J.-F., Gutierrez Rosales, R.O., Tincopa Marca, L.R., Hoffmann, L., Bonierbale, M. and Schafleitner, R. (2010). Identification of drought-responsive compounds in potato through a combined transcriptomic and targeted metabolite approach. Journal of Experimental Botany, 61: 2327-2343.

Forlani, G., Scainel, D. and Nielsen, E. (1997). Two $\Delta^{1}$ pyrroline-5-carboxylate dehydrogenase, isoforms are expressed in cultured Nicotiana plumbaginifolia cells and are differentially modulated during the culture growth cycle. Planta, 20: 242-254

Fougere, F., Le Rudulier, D. and Streeter, J.G. (1991) .Effects of salt stress on amino acid, organic acid, and carbohydrate composition of roots, bacteroids, and cytosol of alfalfa (Medicago sativa L.). Plant Physiology, 96: 1228-1236.

Fowler, S. and Thomashow, F. (2002). Arabidopsis transcriptome profiling indicates that multiple regulatory pathways are activated during cold acclimation in addition to the CBF cold response pathway. The Plant Cell, 14: 8-15.

Funck, D., Stadelhofer, B. and Koch, W. (2008). Ornithine-a -aminotransferase is essential for arginine catabolism but not for proline biosynthesis. BMC Plant Biology, 8: 40-52.

Gangopadhyay G, Basu S, Mukherjee B, Gupta S. (1997). Effects of salt and osmotic shocks on unadapted and adapted callus lines of tobacco. Plant Cell, Tissue and Organ Culture, 49: 45-52.

Ghanti, S.K.K., Sujata, K.G., Kumar, B.M.V., Karba, N.N., Reddy, K.J., Rao, M.S. and Kavi Kishor, P.B. (2011). Heterologous expression of P5CS gene in chickpea enhances salt tolerance without affecting yield. Biologia Plantarum, 55: 634-640.

Gleeson, D., LeluWalter, M. and Parkinson, M. (2005). Overproduction of proline in transgenic hybrid larch [Larix $\times$ leptoeuropaea (Dengler)] cultures renders them tolerant to cold, salt and frost. Molecular Breeding, 15(1): 21-29.

Guerzoni, J.T.S., Belintani, N.G., Moreira, R.M.P., Hoshimo, A.A., Domingues, D.S., Filho, J.C.B. and Vieira, L.G.E. (2014). Stress-induced $\Delta^{1}$-pyrroline-5carboxylate synthetase (P5CS) gene confers tolerance to salt stress in transgenic sugarcane. Acta Physiologiae Plantarum, 36(9): 2309-2319.

Han, K.H. and Hwang, C.H. (2003). Salt tolerance enhanced by transformation of a P5CS gene in carrot. Journal of Plant Biotechnology, 5: 149-153.

Hanson, A.D. and Hitz, W.D. (1982). Metabolic responses of mesophytes to plant water deficits. Annual Reviews of
Plant Physiology, 33: 163-203.

Hanson, A.D., Rathinasabapathi, B., Rivoal, J., Burnet, M., Dillon, M.O. and Gage, D.A. (1994). Osmoprotective compounds in the Plumbaginaceae: a natural experiment in metabolic engineering of stress tolerance. Proceedings of the National Academy of Science USA, 91 (1): 306-310.

Hare, P.D. and Cress, W.A. (1997). Metabolic implications of stress-induced proline accumulation in plants. Plant Growth Regulation, 21(2): 79-102.

Hare, P.D., Cress, W.A. and Van Staden, J. (1998). Dissecting the roles of osmolyte accumulation during stress. Plant Cell and Environment, 21: 535-553.

Hellebust, J.A. (1976). Osmoregulation. Annual Review of Plant Physiology, 27: 485-505.

Hmida-Sayari, A., Gargouri-Bouzid, R., Bidani, A., Jaoua, L., Savoure, A. and Jaoua, S. (2005). Overexpression of $\mathrm{D}^{1}$-pyrroline-5-carboxylate synthetase increases proline production and confers salt tolerance in transgenic potato plants. Plant Science, 169: 746-752.

Hong, Z., Lakkineni, K., Zhang, Z. and Verma, D.P.S. (2000). Removal of feedback inhibition of pyrroline-5carboxylate synthetase results in increased proline accumulation and protection of plants from osmotic stress. Plant Physiology, 122: 1129-1136.

Hongqi, Z., Croes, A.F. and Linskens, H.F. (1982). Protein synthesis in germinating pollen of Petunia: role of proline. Planta, 154: 199-203.

Hoque, M.A., Banu, M.N.A., Nakamura, Y., Shimoishi, Y. and Murata, Y. (2008). Proline and glycinebetaine enhance antioxidant defense and methylglyoxal detoxifi cation systems and reduce $\mathrm{NaCl}$-induced damage in cultured tobacco cells. Journal of Plant Physiology, 165: 813-824.

Hu, C.A, Delauney, A.J. and Verma, D.P. (1992). A bifunctional enzyme ( $\Delta^{1}$-pyrroline-5-carboxylate synthetase) catalyzes the first two steps in proline biosynthesis in plants. Proceedings of National Academy of Science USA, 89(19): 9354-9358.

Hur, J., Hong Jong, K., Lee, C-H. and An, G., (2004). Stress-inducible OsP5CS2 gene is essential for salt and cold tolerance in rice. Plant Science, 167: 417-426.

Ibragimova, S.S., Kolodyazhnaya, S.Y., Gerasimova, S.V. and Kochetov, A.V. (2012). Partial suppression of gene encoding proline dehydrogenase enhances plant tolerance to various abiotic stresses. Russian Journal of Plant Physiology, 59: 88-96.

Ibragimova, S.M., Trifonova, E.A., Filipenko, E.A. and Shymny, V.K. (2015). Evaluation of salt tolerance of transgenic tobacco plants bearing the P5CS1 gene of Arabidopsis thaliana. Russian Journal of Genetics, 51 (12): 1181-1188

Jazii, R.F., Yamchi, A., Hajirezaei, M., Abbasi, A.R. and Karkhane, A.A. (2011). Growth assessments of Nicotiana tabaccum cv. Xanthi transformed with Arabidopsis thaliana P5CS under salt stress. African Journal of Biotechnology, 10: 8539-8552.

Jones, M.M., Osmond, C.B. and Turner, N.C. (1980). Accumulation of solutes in leaves of sorghum and sunflower in response to water deficits. Australian Journal of Plant Physiology, 7: 193-205.

Kant, S., Kant, P., Raveh, E., and Barak, S. (2006). Evidence that differential gene expression between the halophyte, Thellungiella halophila, and Arabidopsis thaliana is 
responsible for higher levels of the compatible osmolyte proline and tight control of $\mathrm{Na}+$ uptake in T. halophila. Plant Cell and Environment, 29: 1220-1234.

Karthikeyan, A., Pandian, S.K. and Ramesh, M. (2011). Transgenic indica rice cv. ADT 43 expressing a $\Delta^{1}$ pyrroline-5-carboxylate synthetase (P5CS) gene from Vigna aconitifolia demonstrates salt tolerance. Plant Cell Tissue and Organ Culture, 107: 383-395.

Kavi Kishor, P.B., Hong, Z., Miao, G., Hu, C.A.A. and Verma, D.P.S. (1995). Over expression of $\Delta^{1}$-pyrroline-5carboxylate synthetase increases proline overproduction and confers osmotolerance in transgenic plants. Plant Physiology, 108: 1387-1394.

Kavi Kishor, P.B., Sangam, S., Amrutha, R.N., Laxmi, P.S., Naidu, K.R., Rao, K.R.S. S., Rao, S., Reddy, K.J., Theriappan, P. and Sreenivasulu, N. (2005). Regulation of proline biosynthesis, degradation, uptake and transport in higher plants: Its implications in plant growth and abiotic stress tolerance. Current Science, 88: 424-438.

Kazuo, S. and Kazuko, Y.S. (2006). Gene networks involved in drought stress response and tolerance. Journal of Experimental Botany, 58(2): 221-227.

Kemble, A.R. and Macpherson, H.T. (1954). Liberation of amino acids in perennial rye grass during wilting. Biochemistry Journal, 58(1): 46-49.

Ketchum, R.E.B, Warren, R.C., Klima, L.J., LopezGutierrez, F. and Nabors, M.W. (1991). The mechanism and regulation of proline accumulation in suspension cultures of the halophytic grass Distichlis spicata L. Journal of Plant Physiology, 137: 368-374.

Kochetov, A.V., Titov, S.E., Kolodyazhnaya, Y.S., Komarova, M.L., Kovel, V.S., Makarova, N.N., Ilyinskyi, Y.Y., Trifonova, E.A. and Shummy, V.K. (2004). Tobacco transformants bearing antisense suppressor of proline dehydrogenase gene are characterized by higher proline content and cytoplasm osmotic pressure. Russian Journal of Genetics, 40: 216-218.

Kreps, J.A., Wu, Y., Chang, H.S., Zhu, T. and Wang, X. (2002). Transcriptome changes for Arabidopsis in response to salt, osmotic, and cold stress. Plant Physiology, 130: 2129-2141.

Kumar, V., Shriram, V., Kavi Kishor, P.B., Jawali, N. and Shitole, M.G. (2010). Enhanced proline accumulation and salt stress tolerance of transgenic indica rice by over expressing P5CSF129A gene. Plant Biotechnology Reports, 4: 37-48.

Kuznetsov, V.V. and Shevyakova, N.I. (1999). Proline under stress: Biological role, metabolism, and regulation. Russian Journal of Plant Physiology, 46: 274-287.

LaRosa, P. C., Rhodes, D., Rhodes, J. C., Bressan, R. A. and Csonka, L. N., (1991). Elevated accumulation of proline in $\mathrm{NaCl}$-adapted tobacco cells is not due to altered $\Delta^{1}$ pyrroline-5-carboxylate reductase. Plant Physiology, 96: 245-250.

Leigh, R.A., Ahmad, N. and Wyn Jones, R.G. (1981). Assessment of glycine betaine and proline compartmentation by analysis of isolated beet vacuoles. Planta, 153 : 34-41.

Leisinger, T. (1987). Biosynthesis of proline. In: Escherichia coli and Salmonella typhimurium: Cellular and Molecular Biology. Neidhardt, F.C., Ingraham, J.L., Low, K.B., Magasanik, B., Schaechter, M. and Umbarger, H.E. (eds.). American Society for Microbiology, Washington, DC. pp. 346-351.
Li, S., Du, Y.P., Wu, Z.Y., Huang, C.L., Zhang, X.H., Wang, Z.X. and Jia, G.X. (2013). Excision of a selectable marker in transgenic lily (Sorbonne) using the Cre/loxP DNA excision system. Canadian Journal of Plant Science, 93: 903-912.

Liu, J., Ishitani, M., Halfter, U., Kim, C.S. and Zhu, J.K. (2000). The Arabidopsis thaliana SOS2 gene encodes a protein kinase that is required for salt tolerance. Proceedings of the National Academy of Sciences, USA, 97: 3730-3734.

Liu D., He, S., Zhai, H., Wang, L., Zhao, Y.B., Wang, R. and Liu. Q. (2014). Overexpression of IbP5CR enhances salt tolerance in transgenic sweet potato. Plant Cell, Tissue and Organ Culture 117: 1-16.

Ma, L., Zhou, E., Gao, L., Mao, X., Zhou, R. and Jia, J. (2008). Isolation, expression analysis and chromosomal location of P5CR gene in common wheat (Triticum aestivum L.). South African Journal of Botany, 74: 705712.

Madan, S., Nainawatee H.S., Jain, R.K., Chowdhury, J.B. (1995). Proline and proline metabolising enzymes in in-vitro selected NaCl-tolerant Brassica juncea L. under salt stress. Annals of Botany, 76: 51-57.

Mahboobeh, R. and Akbar, E.A. (2013). Effect of salinity on growth, chlorophyll, carbohydrate and protein contents of transgenic Nicotiana plumbaginifolia overexpressing P5CS gene. E3 Journal of Environmental Research and Management, 4: 163-170.

Mani, S., Van de Cotte, B., Van Montagu, M. and Verbruggen, N. (2002). Altered levels of proline dehydrogenase cause hypersensitivity to proline and its analogs in Arabidopsis. Plant Physiology, 128: 73-83.

Martin J.H. (1930). The comparative drought resistance of sorghums and corn. Agronomy Journal, 22: 993-1003.

McCue, K.F. and Hanson, A.D. (1990). Drought and salt tolerance: towards understanding and application. Trends in Biotechnology, 8: 358-362.

Miller, G., Honig, A., Stein, H., Suzuki, N., Mittler, R. and Zilberstein, A. (2009). Unraveling $\Delta^{1}$-pyrroline-5carboxylate-proline cycle in plants by uncoupled expression of proline oxidation enzymes. Journal of Biological Chemistry, 284(39): 26482-26492.

Mitchell, H.J., Ayliffe, M.A., Rashid, K.Y. and Pryor, A.J. (2006). A rust inducible gene from flax is involved in proline catabolism. Planta, 223: 213-222.

Molinari, H.B.C., Filho, J.C.B., Kobayashi, A.K., Pileggi, M., Junior, R.P.L. and Pereira, L.F.P. (2004). Osmotic adjustment in transgenic citrus rootstock Carrizo citrange (Citrus sinensis Osb. $\times$ Poncirus trifoliate L. Raf.) overproducing proline. Plant Science, 167: 13751381 .

Molinari, H.B.C., Marur, C.J., Daros, E., Campos, M.K.F., Carvalho, J.F.R.P., Filho, J.C.B., Pereira, L.F.P. and Vieira, L.G.E. (2007). Evaluation of the stress-inducible production of proline in transgenic sugarcane: osmotic adjustment, chlorophyll fluorescence and oxidative stress. Physiologia Plantarum, 130: 218-229.

Monteoliva, M.I, Rizzi, Y.S., Cecchini, N.M., Hajirezaei, M.R. and Alvarez, M.E. (2014). Context of action of proline dehydrogenase (ProDH) in the hypersensitive response of Arabidopsis. BMC Plant Biology, 14: 21-32.

Munns, R. (2005). Genes and salt tolerance: bringing them together. New Phytologist, 167: 645-663.

Munns, R. and Tester, M. (2008). Mechanisms of salinity 
tolerance. Annual Review of Plant Biology, 59: 651-681.

Naidu, B.P., Paleg, L.G., Aspinall, D., Jennings, A.C., Jones, G.P. (1991). Amino acid and glycine betaine accumulation in cold stressed wheat seedlings. Phytochemistry, 30: 407-409.

Nanjo T., Kobayashi, M., Yoshiba, Y., Sanada, Y., Wada, K., Tsukaya, H., Kakubari, Y., Yamagushi-Shinozaki, K. and Shinozaki, K. (1999). Biological functions of proline in morphogenesis and osmotolerance revealed in antisense transgenic Arabidopsis thaliana. The Plant Journal, 18: 185-193.

Nash, D., Paleg, L.G. and Wiskich, J.T. (1982). Effect of proline, betaine and some other solutes on the heat stability of mitochondrial enzymes. Australian Journal of Plant Physiology, 9: 47-57.

Ober, E.S., and Sharp, R.E. (1994). Proline accumulation in maize (Zea mays L.) primary roots at low water potentials. 1. Requirement for increased levels of abscisic acid. Plant Physiology, 105: 981-987.

Pahlich, E., Kerres, R. and Jager, H.J. (1983). Influence of water stress on the vacuole/extravacuole distribution of proline in protoplasts of Nicotiana rustica. Plant Physiology, 72: 590-591.

Paleg, L.G., Douglas, T.J., van Daal, A. and Keech, D.B. (1981). Proline, betaine and other organic solutes protect enzymes against heat inactivation. Australian Journal of Plant Physiology, 8: 107-114.

Parida, A.K., Dagaonkar, V.S., Phalak, M.S., and Aurangabadkar, L.P. (2008). Differential responses of the enzymes involved in proline biosynthesis and degradation in drought tolerant and sensitive cotton genotypes during drought stress and recovery. Acta Physiologiae Plantarum, 30: 619-627.

Petrusa, LM and Winicov, I. (1997). Proline status in salt tolerant and salt sensitive alfalfa cell lines and plants in response to $\mathrm{NaCl}$. Plant Physiology and Biochemistry, 35: 303-310

Phang, J. M. (1985). The regulatory functions of proline and pyrroline- 5-carboxylic acid. Current Topics in Cell Regulation, 25:91-132.

Priya, A.M., Krishnan, S.R. and Ramesh, M. (2015). Ploidy stability of Oryza sativa. L $c v$. IR64 transformed with the moth bean P5CS gene with significant tolerance against drought and salinity. Turkish Journal of Biology, 39: 407-416.

Pollard, A. and Wyn, J.R.G. (1979). Enzyme activities in concentrated solutions of glycinebetaine and other solutes. Planta, 144: 291-298.

Razavizadeh, R. and Ehsanpour, A.A. (2009). Effects of salt stress on proline content, expression of $\Delta^{1}$-pyrroline-5carboxylate synthetase, and activities of catalase and ascorbate peroxidase in transgenic tobacco plants. Biology Letters, 46: 63-75.

Rayapati, P.J. and Stewart, C.R. (1991). Solubilization of proline dehydrogenase from maize (lea mays L.) mitochondria. Plant Physiology, 95: 787-791.

Rhodes, D. (1987). Metabolic responses to stress. In: The Biochemistry of Plants, Davies, D.D. (eds.), vol. 12. Academic Press, New York, pp. 201-241.

Rhodes, D. and Handa, S. (1989). Amino acid metabolism in relation to osmotic adjustment in plant cells. In: Environmental Stress in Plants: Biochemical and Physiological Mechanisms, NATO ASI Series, vol. G19, Cherry, J.H. (eds.), Springer, Berlin, pp. 41-62.
Rhodes, D., Nadolska-Orczyk A., Rich P.J. (2002). Salinity, osmolytes and compatible solutes In: Lauchli A, Luttge U, eds. Salinity, Environment, Plant, Molecules. Netherlands: Al-Kluwer Academic Publishers, pp. 181-204.

Rhodes, D., Verslues, P.E. and Sharp, R.E. (1999). Role of amino acids in abiotic stress resistance. In: Plant Amino Acids: Biochemistry and Biotechnology, Singh, B.K. (eds.) Marcel Dekker, NY, pp. 319-356.

Ribarits, A., Abdullaev, A., Tashpulatov, A., Richter, A., Heberle-Bors, E. and Touraev, A. (2007). Two tobacco proline dehydrogenases are differentially regulated and play a role in early plant development. Planta, 225: 1313-1324.

Rice Knowledge Management Portal (2011). www.rkmp.co.in www.rkmp.iari.res.in.

Rodriguez, R. and Redman, R. (2005). Balancing the generation and elimination of reactive oxygen species. Proceedings of National Academy of Science USA, 102: 3175-3176.

Roosens, N.H., Bitar, F.A., Loenders, K., Angenon, G. and Jacobs, M. (2002). Overexpression of ornthine- $\delta$ aminotransferase increases proline biosynthesis and confers osmotolerance in transgenic plants. Molecular Breeding, 9: 73-80.

Roxas, V.P., Smith, R.K., Allen, E.R. and Allen, R.D. (1997). Overexpression of glutathione S-transferase/ glutathione peroxidase enhances the growth of transgenic tobacco seedlings during stress. Nature Biotechnology, 15: 988-991.

Sairam, R.K., Srivastava, G.C., Agarwal, S. and Meena, R.C. (2005). Differences in response to salinity stress in tolerant and susceptible wheat genotypes. Biologia Plantarum, 49(1): 85-91.

Samaras, Y., Bressan, R.A., Csonka, L.N., Garcia-Rios, M.G., Paino, D'Urzo, M. and Rhodes, D. (1995). Proline accumulation during drought and salinity. In: Environment and Plant Metabolism: Flexibility and Acclimation, Bios Scientific Publishers, Oxford, pp. 161-187.

Sasaki, T., Matsumoto, T., Yamamoto, K., Sakata, K., Baba, T., Katayose, Y., Wu, J., Niimura, Y., Cheng, Z. and Nagamura, Y. (2005). The map-based sequence of the rice genome. Nature, 436: 793-800.

Sawahel, W. A. and Hassan, A. H., (2002). Generation of transgenic wheat plants producing high levels of the osmoprotectant proline. Biotechnology Letters, 24: 721725.

Schat, H., Sharma, S.S. and Vooijs, R. (1997). Heavy metalinduced accumulation of free proline in a metaltolerant and a nontolerant ecotype of Silene vulgaris. Physiologia Plantarum, 101: 477-482.

Schwacke, R., Grallath, S., Breitkreuz, K.E., Stransky, E., Stransky, H., Frommer, W.B., and Rentsch, D. (1999). LeProT1, a transporter for proline, glycine betaine, and $\gamma$-amino butyric acid in tomato pollen. Plant Cell, 11: 377-392.

Seki, M., Kamei, A., Yamaguchi-Shinozaki, K. and Shinozaki, K. (2003). Molecular responses to drought, salinity and frost: common and different paths for plant protection. Current Opinion in Biotechnology, 14: 194-199.

Seki, M., Narusaka, M., Ishida, J., Nanjo, T. and Fujita, M. (2002). Monitoring the expression profiles of $7000 \mathrm{Ara}$ bidopsis genes under drought, cold and high-salinity stresses using a full-length cDNA microarray. Plant Journal, 31: 279-92.

Serraj, R. and Sinclair, T.R. (2002). Osmolyte accumulation: 
can it really help increase crop yield under drought conditions. Plant Cell Environment, 25: 333-341.

Serrano, R., Mulet, J.M., Rios, G., Marquez, J.A., Larrinoa, I.F., Leube, M.P., Mendizabal, I., Pascual-Ahuir, A., Proft, M., Ros, R. and Montesinos, C. (1999). A glimpse of the mechanisms of ion homeostasis during salt stress. Journal of Experimental Botany, 50: 10231036.

Sharma, S.S. and Dietz, K.J. (2006). The significance of amino acids and amino acid-derived molecules in plant responses and adaptation to heavy metal stress. Journal of Experimental Botany, 57: 711-726.

Sharma, S., and Verslues, P.E. (2010). Mechanisms independent of $\mathrm{ABA}$ or proline feedback have a predominant role in transcriptional regulation of proline metabolism during low water potential and stress recovery. Plant Cell and Environment, 33: 1838-1851.

Shen, B., Hohmann, S., Jensen, R.G. and Bohnert, H.J. (1999). Roles of sugar alcohols in osmotic stress adaptation. Replacement of glycerol by mannitol and sorbitol in yeast. Plant Physiology, 121: 45-52.

Siripornadulsil, S., Traina, S., Verma, D.P.S. and Sayre, R.T. (2002). Molecular mechanisms of proline-mediated tolerance to toxic heavy metals in transgenic microalgae. Plant Cell, 14: 2837-2847.

Smirnoff, N. and Cumbes, Q.J. (1989). Hydroxyl radical scavenging activity of compatible solutes. Phytochemistry, 28: 1057-1060.

Sokhansanj, A., Noori, S.A.S. and Niknam, V. (2006). Comparison of bacterial and plant genes participating in proline biosynthesis with Osmotin gene, with respect to enhancing salinity tolerance of transgenic tobacco plants. Russian Journal of Plant Physiology, 53: 110-115.

Somero, G.N. (1986). Protons, osmolytes, and fitness of internal milieu for protein function. American Journal of Physiology, 251: 197-213.

Srinivas, V. and Balasubramanian, D. (1995). Proline is a protein-compatible hydrotrope. Langmuir, 11: 28302833.

Stephanopoulos, G. (1999). Metabolic fluxes and metabolic engineering. Metabolic Engineering, 1: 1-11.

Stewart, G.R. and Lee, J.A. (1974). The role of proline accumulation in halophytes. Planta, 120: 279-289.

Stewart, C.R., Boggess, S.F., Aspinall, D. and Paleg, L.G. (1977). Inhibition of proline oxidation by water stress. Plant Physiology, 59: 930-932.

Stewart G.R. and Larher, F. (1980). Accumulation of amino acids and related compounds in relation to environmental stress. In: The Biochemistry of Plants. Mifflin, B.J. (eds), vol. 5, Academic Press, New York, pp. 609-635.

Stewart, C.R. (1981). Proline accumulation: Biochemical aspects. In: Physiology and Biochemistry of Drought Resistance in Plants, Paleg, L.G. and Aspinall, D. (eds.) Academic Press, Sydney, pp. 243-259.

Stines, A.P., Naylor, D.J., Hoj, P.B. and van Heeswijck, R. (1999). Proline accumulation in developing grapevine fruit occurs independently of changes in the levels of $\Delta^{1}$ -pyrroline-5-carboxylate synthetase mRNA or protein. Plant Physiology, 120: 923-931.

Strizhov N, Abrahám E, Okrész L, Blickling S, Zilberstein A, Schell J, (1997). Differential expression of two P5CS genes controlling proline accumulation during salt-stress requires $\mathrm{ABA}$ and is regulated by $\mathrm{ABA} 1$, ABI1 and AXR2 in Arabidopsis. Plant Journal, 12: 557
$-569$

$\mathrm{Su}, \mathrm{J} ., \mathrm{Wu}, \mathrm{R}$. (2004). Stress inducible synthesis of proline in transgenic rice confers faster growth under stress conditions than that with constitutive synthesis. Plant Science, 166: 941-948.

Surekha, C., Nirmala Kumari, K., Aruna, L.V., Suneetha, G., Arundhati, A. and Kishor, P.B.K. (2014). Expression of the Vigna aconitifolia P5CSF129A gene in transgenic pigeonpea enhances proline accumulation and salt tolerance. Plant Cell Tissue and Organ Culture, 116: $27-$ 36.

Surender Reddy, P., Jogeswar, G., Rasineni, G.K., Maheswari, M., Reddy, A.R., Varshney, R.K. and Kavi Kishor, P.B. (2015). Proline over-accumulation alleviates salt stress and protects photosynthetic and antioxidant enzyme activities in transgenic sorghum (Sorghum bicolor L. Moench). Plant Physiology and Biochemistry, 94: 104-113.

Szekely, G., Abraham, E., Cselo, A., Rigo, G., Zsigmond, L., Csiszar, J., Ayaydin, F., Strizhov, N., Jasik, J., Schmelzer, E., Koncz, C. and Szabados, L. (2008). Duplicated P5CS genes of Arabidopsis play distinct roles in stress regulation and developmental control of proline biosynthesis. Plant Journal, 53: 11-28.

Szymon, K., Lukasz, Q., Katarzyna, L., Stanley, L. and Malgorzata, G. (2015). Enhanced expression of the proline synthesis gene P5CSA in relation to seed osmopriming improvement of Brassica napus germination under salinity stress. Journal of Plant Physiology, 183: $1-12$.

Tal, M. and Katz, A. (1980). Salt tolerance in the wild relatives of the cultivated tomato: the effect of proline on the growth of callus tissue of Lycopersicon esculentum and $L$. peruvianum under salt and water stress. Z. Pflanzenphysiol, 98: 283-288.

Tanner, J. (2008). Structural biology of proline catabolism. Amino Acids, 35: 719-730.

Taylor, C.B. (1996). Proline and water deficit: ups and downs. Plant Cell, 8: 1221-1224.

Thomas, J.C., De Armond, R.L. and Bohnert, H.J. (1992). Influence of $\mathrm{NaCl}$ on growth, proline, and phosphoenolpyruvate carboxylase levels in Mesembryanthemum crystallinum suspension cultures. Plant Physiology, 98: 626-631.

Thompson, J.F. (1980). Arginine synthesis, proline synthesis, and related processes. In: The Biochemistry of Plants, Mifflin, B.J. (eds.), vol. 5, Academic Press, New York, pp. 375-403.

Timasheff, S.N. (1993). The control of protein stability and association by weak interactions with water: how do solvents affect these processes? Annual Review of Biophysical and Biomolecular Structures, 22: 67-97.

Treichel, S. (1986). The influence of $\mathrm{NaCl}$ on $\Delta^{1}$-pyrroline-5carboxylate reductase (P5CR) in proline-accumulating cell suspension cultures of Mesembryanthemum nodiflorum and other halophytes. Plant Physiology, 67: 173-181.

Ueda, A., Shi, W., Shimada, T., Miyake, H. and Takabe, T. (2008). Altered expression of barley proline transporter causes different growth responses in Arabidopsis. Planta, 227(2): 277-86.

Vendruscoloa, E.C.G., Schusterb, I., Pileggic, M., Scapimd, C.A., Molinarie, H.B.C., Marure, C.J. and Vieirae L.G.E. (2007). Stress-induced synthesis of proline 
confers tolerance to water deficit in transgenic wheat Journal of Plant Physiology, 164: 1367-1376.

Verbruggen, N. and Hermans, C. (2008). Proline accumulation in plants: a review. Amino Acids, 35: 753-759.

Verbruggen, N., Hua, X.J., May, M. and Van Montagu, M. (1996). Environmental and developmental signals modulate proline homeostasis: evidence for a negative transcriptional regulator. Proceedings of National Academy of Science USA, 93: 8787-8791.

Verdoy, D., de la Pena, T.C., Redondo, F.J., Lucas, M.M. and Pueyo, J.J. (2006). Transgenic Medicago truncatula plants that accumulate proline display nitrogen fixing activity with enhanced tolerance to osmotic stress. Plant, Cell and Environment, 29: 1913-1923.

Verma, D.P.S. (1999). Osmotic stress tolerance in plants: Role of proline and sulfur metabolisms. In: Molecular Responses to Cold, Drought, Heat and Salt Stress in Higher Plants. Landes Company, Texas, USA, pp. 153 -168 .

Voetberg, G.S. and Sharp, R.E. (1991). Growth of the maize primary root tip at low water potentials. III. Role of increased proline deposition in osmotic adjustment. Plant Physiology, 96: 1125-1130.

Widodo, John, H.P., Ed, N., Mark, T., Antony, B. and Ute, R. (2009). Metabolic responses to salt stress of barley (Hordeum vulgare L.) cultivars, Sahara and Clipper, which differ in salinity tolerance. Journal of Experimental Botany, 60: 4089-4103.

Williamson, C. L. and Slocum, R. D. (1992). Molecular cloning and evidence for osmoregulation of the D 1 pyrroline-5-carboxylate reductase (proC) gene in pea (Pisum sativum L.). Plant Physiology, 100: 1464-1470

Wu, S.J., Ding, L. and Zhu, J.K. (1996). SOS1 a genetic locus essential for salt tolerance and potassium acquisition. Plant Cell, 8: 617-627.

Wu, L.Q., Fan, Z.M., Guo, L., Li, Y.Q., Zhang, W.J., Qu, L.J. and Chen, Z.L. (2003). Over-expression of an Arabidopsis delta-OAT gene enhances salt and drought tolerance in transgenic rice. Chinese Science Bulletin, 48: 2594-2600.

Wyn, J.R.G., Storey, R., Leigh, R.A., Ahmad, N. and Pollard. A. (1977). A hypothesis on cytoplasmic osmoregulation. In: Regulation of Cell Membrane Activities in Plants. Marre, E. and Cifferi, O. (eds.), Elsevier, Amsterdam, $p p$. 121-136.

Yamchi A., Jazii, F.R., Mousav, A., Karkhane, A.A. and Re, S. (2007). Proline accumulation in transgenic tobacco as a result of expression of Arabidopsis $\Delta^{1}$-pyrroline-5carboxylate synthetase (P5CS) during osmotic stress. Journal of Plant Biochemistry and Biotechnology, 16: 9 -15 .

Yancey, P.H. (1994). Compatible and counteracting solutes. In: Cellular and Molecular Physiology of Cell Volume Regulation. Strange, K. (eds.), CRC Press, Boca Raton, pp. 81-109.

Yancey, P.H., Clark, M.E., Hand, S.C., Bowlus, R.D. and Somero, G.N. (1982). Living with water stress: evolution of osmolytes systems. Science, 217: 1214-1222.

You, J., Hu, H. and Xiong L. (2012). An ornithine $\alpha$ aminotransferase gene OsOAT confers drought and oxidative stress tolerance in rice. Plant Science, 197: 59 $-69$.

Yu, C., Wan, A.S, Auinbt, Z.A. and Quzac, G.J. (1983) Transport of glycine, serine, and proline into spinach leaf mitochondria. Archives of Biochemistry and Biophysics, 227: 180-187.

Zhang, C.S., Lu, Q. and Verma, D.P.S. (1995). Removal of feedback inhibition of $\Delta^{1}$-pyrroline-5-carboylate synthetase, a bifunctional enzyme catalyzing the first two steps of proline biosynthesis in plants. Journal of Biological Chemistry, 270: 20491-20496.

Zhu, B., Su, J., Chang, M., Verma, D. P. S., Fan, Y. L. and $\mathrm{Wu}$, R. (1998). Overexpression of a $\Delta^{1}$-pyrroline-5carboxylate synthetase gene and analysis of tolerance to water-and salt-stress in transgenic rice. Plant Science, 139: 41-48. 